\title{
Cytogenetic and Molecular Characterization of Hematological Neoplasm in an Ecuadorian Population
}

\author{
César Paz-y-Miño ${ }^{1}$, María Eugenia Sánchez ${ }^{1}$, Santiago Araujo ${ }^{1}$, Ligia Ocampo ${ }^{2}$, \\ Víctor Hugo Espín ${ }^{3}$, Paola E. Leone ${ }^{1}$
}

${ }^{1}$ Instituto de Investigaciones Biomédicas, Universidad de las Américas, Quito, Ecuador; ${ }^{2}$ Laboratorio de Genética, Sociedad de Lu-
cha contra el Cáncer (SOLCA), Quito, Ecuador; ${ }^{3}$ Laboratorio de Genética, Hospital Carlos Andrade Marín, Quito, Ecuador.
Email: cpazymino@udla.edu.ec

Received September $19^{\text {th }}, 2013$; revised October $19^{\text {th }}, 2013$; accepted October $26^{\text {th }}, 2013$

Copyright (C) 2013 César Paz-y-Miño et al. This is an open access article distributed under the Creative Commons Attribution License, which permits unrestricted use, distribution, and reproduction in any medium, provided the original work is properly cited. In accordance of the Creative Commons Attribution License all Copyrights (C 2013 are reserved for SCIRP and the owner of the intellectual property César Paz-y-Miño et al. All Copyright (C) 2013 are guarded by law and by SCIRP as a guardian.

\begin{abstract}
Cancer is one of the major causes of mortality in Ecuador and annually, hematological malignancies are within the top ten most common cancers. In this multicentric study, we analyzed a series of patients diagnosed with different hematological disorders between the years 1984 and 2012. Chromosome abnormalities were detected in 1886 (45.9\%) patients. FISH and RT-PCR techniques were used in order to determine the presence of genetic rearrangements and complement conventional cytogenetics results. Using FISH and RT-PCR, positive cases were increased by $1.8 \%$ and $6.9 \%$ respectively. We analyzed fusion genes resulting from $\mathrm{t}(8 ; 21), \mathrm{t}(15 ; 17)$, inv(16), $\mathrm{t}(9 ; 22), 11 \mathrm{q} 23$ rearrangements, $\mathrm{t}(4 ; 11)$ and $\mathrm{t}(1 ; 19)$. The frequency of transcripts of some of these fusion genes was of particular interest as our results differ from studies on other populations. Specifically, the fusion gene $B C R-A B L$ was present in the form of the b2/a 2 transcript in $95 \%$ of CML patients and in the form of b3/a 2 transcript in the remaining 5\%. The $P M L-R A R A$ fusion gene also showed a distinct pattern of transcript expression. This fusion gene exhibited the bcr2 (36\%) and bcr3 (64\%) transcripts, however the bcrl transcript was absent from our sample population. All cases carrying the $C B F B-M Y H 11$ fusion gene exhibited the $\mathrm{F}$ transcript. This was also of interest due to the rarity of this particular transcript worldwide. Finally all cases carrying the $M L L-A F 4$ fusion gene displayed the e7-e8 transcript. The frequency of the subtypes of some fusion genes differ from those reported in other populations, possibly due to the particular genetic make-up of the Ecuadorian population, mostly mestizo, as well as environmental factors.
\end{abstract}

Keywords: Hematological Diseases; Chromosomal Aberration; BCR-ABL; PML-RARA; CBFB-MYH11; MLL-AF4; Geographical Heterogeneity

\section{Introduction}

Hematological disorders are an important cause of morbidity and mortality in the entire world. A database produced by the Leukemia and Lymphoma Society-USA (updated in 2013), shows the following rates per 100,000 inhabitants worldwide: 12.8 for leukemia, 19.7 for NonHodgkin lymphomas (NHL), 2.8 for Hodgkin's lymphoma (HL), and 5.9 for myeloma [1].

The equivalent in Ecuador is produced by the National Cancer Registry of SOLCA [2], located in the city of Quito (capital of Ecuador), which reports that in the period of 2001 to 2005 tumors of the hematopoietic and reticuloendothelial systems are within the 25 most fre- quent malignancies, occupying the fourth place $(5.5 \%)$ in males, and the sixth place $(4.5 \%)$ in females. During the 2003-2005 period, analysis of the average annual incidence of their malignancies shows a crude rate of 9.3 $(5.3 \%)$ and $9.1(4.6 \%)$ in males and females respectively. Hodgkin's lymphoma (HL) has a crude rate of 1.4 and 0.4 , follicular (nodular) NHL 0.8 and 0.9 , diffuse NHL 4.7 and 3.9, peripheral and cutaneous t-cell lymphomas 0.8 and 0.7 and other types of NHL 3.2 and 3.0 in males and in females, respectively. The crude rate for Multiple Myeloma (MM) and plasma cell neoplasms, in the same period of time is 2.1 for males and 1.5 for females, for lymphoid leukemia (LL) is 3.9 and 4.3 , for myeloid leukemia (ML) is 2.5 and 2.7, for monocytic leukemia is 0.1 
in males and for leukemia of unspecified cell type is 0.6 and 0.5 , in males and females respectively, finally the myelodysplastic syndrome (MDS) shows a crude rate of 0.1 . Hematopoietic and reticuloendothelial system malignancies have an average annual mortality rate of 5.0 in males and 4.4 in females per 100,000. According to the relative position of the 25 most frequent malignant tumors in males, in the period 2001-2005, lymphoma (6\%) and leukemia (4\%) are in the fourth and fifth places respectively, with MM and malignant plasma cell neoplasms in the 21 st place with $1.1 \%$. Data in females differs slightly, showing $4.3 \%$ in lymphoma (sixth place), $3.6 \%$ leukemia (eighth place) and $\mathrm{MM}$ and malignant plasma cell neoplasms in the 25 th place with $0.6 \%$. LL (56\%) has been reported as the most common in the general population of Quito and ML is $36 \%$. The latter, is more frequent in adults and represents $58 \%$. Regarding lymphomas, the most frequent is diffuse NHL (44\%), followed by follicular NHL (10\%), HL (10\%) and finally $\mathrm{T}$ cell Lymphoma, peripheral and cutaneous lymphomas (6\%) [2]. A study among indigenous people in the Amazon region of Ecuador, reported that leukemia was one of the most common type of cancer in that population [3].

Ecuador's data are also reported by the International Agency for Research in Cancer, through the GLOBOCAN project, showing an estimated incidence (2008) of crude rates for leukemia at 6.1, 5.1 for NHL, 0.9 for MM and 1.2 for HL; therefore it would be interesting to compare these results to worldwide data which reports crude rates of 5.2 in leukemia, 5.3 in NHL, 1.5 in MM and 1.0 in HL [4].

Acute myeloid leukemia (AML) is the most common leukemia in adults. The main genetic abnormalities related to this disorder are: $\mathrm{t}(8 ; 21), \operatorname{inv}(16)$ and $\mathrm{t}(16 ; 16)$ and $\mathrm{t}(15 ; 17)$ [5], which have been reported in other studies with incidences of 0 to $4 \%$ [6,7]. Rearrangements of chromosome 11 (11q23) are observed in $4 \%-10 \%$ of AML patients [8]. The following three new rearrangements related to AML have also been reported: $t(6 ; 9)$, $\operatorname{inv}(3)$ or $\mathrm{t}(3 ; 3)$ and $\mathrm{t}(1 ; 22)$. Regarding chromosomal numerical aberrations, trisomy 8 is the most common in AML [5].

Acute lymphoblastic leukemia (ALL) is the most frequent hematological disorder in children, with $\mathrm{t}(12 ; 21)$ being the most frequent abnormality [9]. The second most frequent alteration is $\mathrm{t}(9 ; 22)$, otherwise known as Philadelphia chromosome $(\mathrm{Ph})$ which present in approximately $5 \%$ of children and $20 \%$ of adults with ALL [10].

So far few studies have analyzed the incidence of molecular alterations in ALL within Latin America. Frequency analysis for the MLL-AF4, TEL-AML1 and BCR-ABL genes in children from Mexico City, reported $65.4 \%$ for the first rearrangement and $3.8 \%$ for the two remaining [11]. In a Peruvian population PML-RAR $\alpha$ presence was analyzed in patients with acute promyelocytic leukemia (APL) and the results showed that the bcrl subtype was present in $62 \%$ of individuals [12]. Another study performed on a group of patients also originated from Latin America showed 75\% for bcr $1,10 \%$ for bcr2 and $15 \%$ for bcr3 [13].

Chromosome $\mathrm{Ph}$ is considered the initial event in Chronic Myelogenous Leukemia (CML), as the result of the BCR-ABL gene fusion [14]; it was reported that $92 \%$ of CML patients were positive for the BCR-ABL gene, specifically b3a2 (61\%) and b2a2 (31\%) [15]. However, frequencies of the different isoforms in Ecuador vary and are as follows: b2-a2 (94.6\%) y b3-a2 (5.4\%) in CML [16]. Atypical b3a3 rearrangement was also described by our group in a patient with a good response to INFalpha treatment [17].

There is not a registry of genetic alterations of the hematological disorders in Ecuador. Therefore, this study is the first to combine information from three reference centers, which perform genetic analyses in samples of patients from all over the country.

The main objective of this study is to delineate a genetic database of hematological disorders that affect the Ecuadorian population and at the same time compare our results to studies from other countries. This group of blood disorders is characterized by geographic heterogeneity of chromosomal and molecular abnormalities. These regional variations, as well as variation in the types of medical practices, quality of treatment and age (which may differ amongst different cities) influence the frequency of cancer diagnoses and patients' deaths. [1820]. The combination of data will help achieve more accurate diagnostics, through the interchanges of cytogenetic and molecular findings that complement each other, which will improve the treatment and management of patients with leukemia and lymphoma.

\section{Methods}

We analyzed 4108 patients with various hematological malignancies, between 1984 and 2012, who were referred to the genetic study from ten institutions from different cities of Ecuador. The hematological diseases were diagnosed according to the WHO classification.

Cytogenetic analysis was performed in bone marrow cells immediately after collection. G-banding technique was performed using standard approaches, and was aimed at identifying structural and numerical alterations, which were classified according to the International System for Human Cytogenetic Nomenclature [21].

Cytogenetic results were classified into five subgroups: Normal karyotype, hyperdiploid, hypodiploid, translocation and complex karyotype. The translocation group included $\mathrm{t}(8 ; 21), \mathrm{t}(15 ; 17), 11 \mathrm{q} 23$ rearrangements, $\mathrm{t}(1 ; 19)$ and $t(9 ; 22)$ that are specifically associated with the ALL, 
AML and CML. The presence of three or more chromosomal alterations and the non-frequent chromosomal abnormalities in the hematopoietic malignancies of this study were classified as complex karyotype group.

Patients were divided into two age groups. The pediatric group which consisted of patients $\leq 15$ years, and the adult group of patients $>16$ years of age [22,23].

The fusion genes were detected using the $\mathrm{t}(8 ; 21)$ (q22;q22), t(15;17) (q21;q22), inv(16)/t(16;16)(p13;q22), $\mathrm{t}(9 ; 22)(\mathrm{q} 34 ; \mathrm{q} 11.2), \mathrm{t}(1 ; 19)(\mathrm{q} 23 ; \mathrm{p} 13.3), \mathrm{t}(12 ; 21)(\mathrm{p} 13 ; \mathrm{q} 22)$ and translocations involving $11 \mathrm{q} 23$ and $8 \mathrm{q} 24.1$ probes (Vysis RUNX1/RUNX1T1 DF FISH Probe Kit; Vysis LSI PML/RARA Dual Color Single Fusion Probes; Vysis LSI CBFB Break Apart Rearrangement Probe; Vysis LSI BCR/ABL Dual Color, Single Fusion Translocation Probe; LSI TCF3/PBX1 Dual Color, Dual Fusion Translocation Probe; Vysis LSI ETV6(TEL)/ RUNX1(AML1) ES Dual Color Translocation Probe Set; Vysis LSI MLL Dual Color, Break Apart Rearrangement Probe; and Vysis LSI MYC Dual Color Break Apart Rearrangement Probe, respectively) according to the manufacturer's instructions (Abbott). Two hundred cells were analyzed for each sample, and normal blood cells were used as a negative control.

Total and messenger RNA was extracted from bone marrow samples, using methods previously described [24]. Analysis by reverse transcriptase-polymerase chain reaction of the RNA of the samples was carried using nested primers defining the junction site of the chimeric gene AML1-ETO, PML-RARA, CBFB-MYH11, BCR-ABL, E2A/PBX1 and AF4-MLL using primers previously described [25].

\section{Results}

\subsection{Clinical Data}

Out of the 4108 newly diagnosed patients with different hematological malignancies, 2326 (56.7\%) patients were male and $1780(43.3 \%)$ patients were female. Patient age ranged from one month to 87 years, with a median age of 43 years. The different malignancies included 715 AML, 1260 ALL, 168 MDS, 52 myeloproliferative disorder (MPD), 945 CML, 15 polycythemia vera (PV), 63 essential thrombocythemia (ET), 104 chronic lymphocytic leukemia (CLL), 10 hairy cell leukemia (HCL), 4 monoclonal gammopathy of undetermined significance (MGUS), $165 \mathrm{MM}, 2$ plasma cell leukemia (PCL), 1 Waldenstrom macroglobulinemia (WM), 14 medular aplasia, 5 Fanconi anemia (FA), $80 \mathrm{HL}$, and $505 \mathrm{NHL}$ cases (Figure 1). These cases were categorized by age and sex and are shown in Figures 2 and 3.

\subsection{Conventional Cytogenetics}

We used conventional cytogenetics to analyze a minimum of 20 metaphases per patient in 4108 patients. As
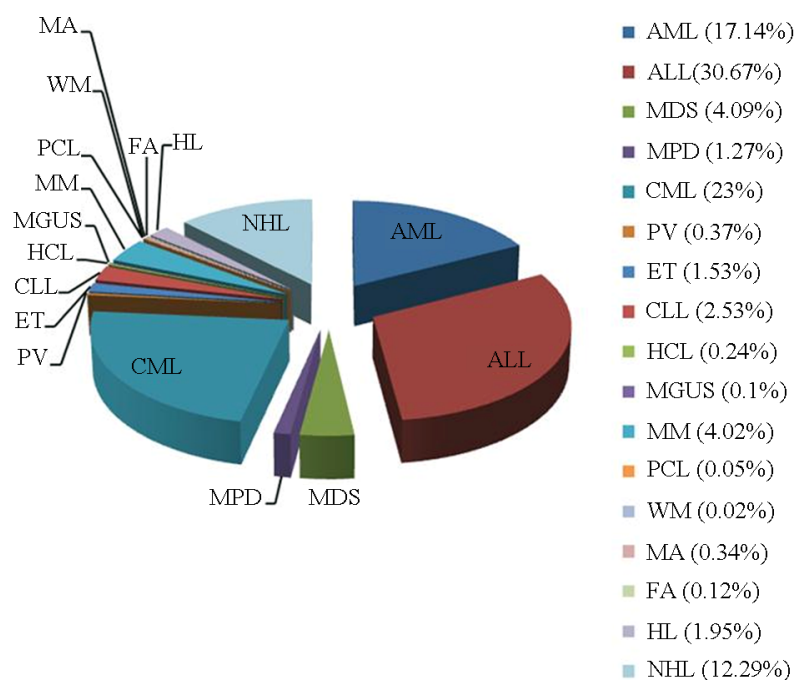

Figure 1. Types of hematological diseases in which genetic study was conducted in Ecuadorian population, 1984-2012.

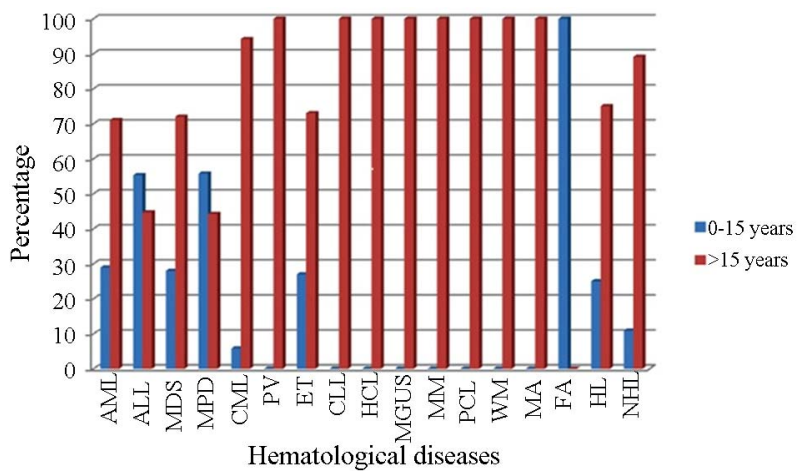

Figure 2. Hematological diseases analyzed by group of age in the Ecuadorian population.

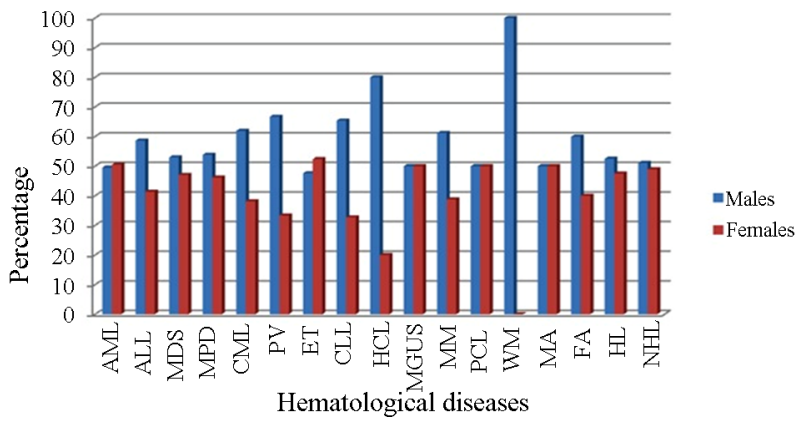

Figure 3. Hematological diseases analyzed by gender in the Ecuadorian population.

shown in Table 1, chromosome abnormalities were detected in 1886 (45.9\%) patients, whereas 1405 (34.2\%) patients had a normal karyotype. Chromosome abnormalities included numeric chromosome changes $(24.6 \%$ patients), structural chromosome changes $(50.6 \%$ patients), and complex karyotypes (24.8\% patients). The rest of the samples were not in metaphase and therefore were not classified by this technique. Within the struc- 
Table 1. Cytogenetics findings in Ecuadorian patients with hematological neoplasm.

\begin{tabular}{|c|c|c|c|c|c|c|c|c|c|c|c|c|c|}
\hline \multirow{3}{*}{$\begin{array}{l}\text { Hematological } \\
\text { Diseases }^{\mathrm{a}}\end{array}$} & \multirow{3}{*}{$\begin{array}{c}\text { Cases } \\
\text { (n) }\end{array}$} & \multirow{2}{*}{\multicolumn{2}{|c|}{ Normal Karyotype }} & \multicolumn{8}{|c|}{ Altered Karyotype } & \multirow{2}{*}{\multicolumn{2}{|c|}{ No Methaphases }} \\
\hline & & & & \multicolumn{2}{|c|}{ Hyperdiploid } & \multicolumn{2}{|c|}{ Hypodiploid } & \multicolumn{2}{|c|}{ Translocation } & \multicolumn{2}{|c|}{ Complex } & & \\
\hline & & $\mathrm{n}$ & $\%$ & $\mathrm{n}$ & $\%$ & $\mathrm{n}$ & $\%$ & $\mathrm{n}$ & $\%$ & $\mathrm{n}$ & $\%$ & $\mathrm{n}$ & $\%$ \\
\hline AML & 715 & 259 & 36.2 & 66 & 9.2 & 57 & 8.0 & 68 & 9.5 & 110 & 15.4 & 155 & 21.7 \\
\hline ALL & 1260 & 419 & 33.3 & 102 & 8.1 & 92 & 7.3 & 99 & 7.9 & 191 & 15.2 & 357 & 28.3 \\
\hline MDS & 168 & 75 & 446 & 15 & 8.9 & 9 & 5.4 & 4 & 2.4 & 20 & 11.9 & 45 & 26.8 \\
\hline MPD & 52 & 26 & 50.0 & 8 & 15.4 & 3 & 5.8 & 3 & 5.8 & 8 & 15.4 & 4 & 7.7 \\
\hline CML & 945 & 100 & 10.6 & 6 & 0.6 & 6 & 0.6 & 756 & 80.0 & 10 & 1.1 & 67 & 7.1 \\
\hline PV & 15 & 9 & 60.0 & 1 & 6.7 & 1 & 6.7 & 0 & 0 & 0 & 0 & 4 & 26.7 \\
\hline ET & 63 & 35 & 55.6 & 0 & 0 & 1 & 1.6 & 1 & 1.6 & 4 & 6.3 & 22 & 34.9 \\
\hline CLL & 104 & 46 & 44.2 & 7 & 6.7 & 5 & 4.8 & 2 & 1.9 & 15 & 14.4 & 29 & 27.9 \\
\hline $\mathrm{HCL}$ & 10 & 5 & 50.0 & 1 & 10.0 & 0 & 0 & 0 & 0 & 0 & 0 & 4 & 40.0 \\
\hline MGUS & 4 & 3 & 75.0 & 0 & 0 & 0 & 0 & 0 & 0 & 0 & 0 & 1 & 25.0 \\
\hline $\mathrm{MM}$ & 165 & 63 & 38.2 & 14 & 8.5 & 7 & 4.2 & 8 & 4.8 & 30 & 18.2 & 43 & 26.1 \\
\hline PCL & 2 & 1 & 50.0 & 0 & 0 & 0 & 0 & 0 & 0 & 0 & 0 & 1 & 50.0 \\
\hline WM & 1 & 1 & 100.0 & 0 & 0 & 0 & 0 & 0 & 0 & 0 & 0 & 0 & 0 \\
\hline MA & 14 & 5 & 35.7 & 0 & 0 & 0 & 0 & 0 & 0 & 2 & 14.3 & 7 & 50.0 \\
\hline FA & 5 & 2 & 40.0 & 0 & 0 & 0 & 0 & 0 & 0 & 3 & 60.0 & 0 & 0 \\
\hline HL & 80 & 56 & 70.0 & 3 & 3.8 & 2 & 2.5 & 0 & 0 & 9 & 11.3 & 10 & 12.5 \\
\hline NHL & 505 & 300 & 59.4 & 30 & 5.9 & 27 & 5.3 & 14 & 2.8 & 66 & 13.1 & 68 & 13.5 \\
\hline Total & 4108 & & & & & & & & & & & & \\
\hline
\end{tabular}

$\overline{{ }^{a} A L L}$, Acute Lymphoblastic Leukemia; AML, Acute Myeloid Leukemia; MDS, Myelodysplastic Syndromes; MPD, Myeloproliferative Disease; CML, Chronic Myeloid Leukemia; PV, Polycythemia vera; ET, Essential Thrombocythemia; CLL, Chronic lymphocytic leukemia; HCL, Hairy cell leukemia; MGUS, monoclonal gammopathy of undetermined significance; MM, Myeloma Multiple; PCL, Plasma Cell Leukemia; WM, Waldenstrom Macroglobulinemia; FA, Fanconi Anemia; MA, Medullary Aplasia; HL, Hodgkin Lymphoma; NHL, Non-Hodgkin Lymphoma.

tural chromosomal changes the most common translocations were $\mathrm{t}(8 ; 21), \mathrm{t}(15 ; 17), 11 \mathrm{q} 23$ rearrangements, $\mathrm{t}(1$; 19) and $t(9 ; 22)$ and were associated hematologic neoplasms.

The most frequent chromosomal alterations reported in leukemia were also detected in this study. Some of the most important found are the following:

In AML the main chromosomal alterations found were $\mathrm{t}(8 ; 21)(4.3 \%), \mathrm{t}(15 ; 17)(3 \%), \operatorname{inv}(16)(1.3 \%), \mathrm{t}(9 ; 11)$ $(1 \%)$, trisomy $8(4 \%)$ and other translocations $(5.3 \%)$. The most frequent in ALL were $\mathrm{t}(9 ; 22)(15.5 \%), \mathrm{t}(1 ; 19)$ $(4.8 \%), \mathrm{t}(4 ; 11)(1.2 \%), 11 \mathrm{q} 23$ rearrangements and $\mathrm{t}(8 ; 14)$ $(0.4 \%$ each). $\mathrm{t}(9 ; 22)$ was detected in $80 \%$ of CML cases. In MM cases, $8.5 \%$ of the cases showed rearrangements of chromosome 14 . In NHL $20 \%$ of the altered metaphases showed translocations.

\subsection{FISH Evaluation}

FISH was performed in samples of patients without metaphases or with normal karyotype; the probes used were those of the most frequent rearrangements in leukemia. We found alterations in 13/715 AML patients, 31/1260 ALL patients and 7/945 CML patients, which increased our positive results by $2 \%, 2.5 \%$ and $1 \%$ respectively (Table 2).

\subsection{Molecular Study}

The results obtained by FISH were consistent with the results of molecular analysis (Table 2). In cases without metaphases, alterations were detected in 22/715 AML patients, 29/1260 ALL patients and 65/945 CML patients, which increased positive results in $3.1 \%, 2.3 \%$ and $6.9 \%$ respectively comparing to conventional cytogenetics results.

Cases in which $\mathrm{t}(8 ; 21)$ was detected by FISH also showed the AML1-ETO RT-PCR product. AML patients with PML-RARA rearrangements presented the bcr2 transcript (36\%) as well as the bcr3 transcript (64\%), however, none of them presented the bcr1 transcript. The CBFB-MYH11 fusion transcript was present in 7 patients, all diagnosed with ALL; all of these the presented the type $\mathrm{F}$ transcript.

The BCR-ABL fusion gene was detected using RTPCR in all $t(9 ; 22)$ positive ALL cases; all of the aforementioned samples showed the e1-a2 transcript. Among the 11q23 rearrangements found in 10 patients 
Table 2. Positive results in AML, ALL and CML cases without metaphases and normal karyotypes.

\begin{tabular}{|c|c|c|c|c|}
\hline \multicolumn{2}{|c|}{ FISH } & \multicolumn{3}{|c|}{ RT-PCR } \\
\hline \multicolumn{5}{|l|}{ AML } \\
\hline Probe & No. Cases ${ }^{\mathrm{a}}$ & Fusion Gene & No. Cases ${ }^{\text {b }}$ & Transcripts \\
\hline $\mathrm{t}(8 ; 21)$ & 4 & AML1-ETO & 4 & \\
\hline $\mathrm{t}(15 ; 17)$ & 5 & $P M L-R A R A$ & $11^{\mathrm{c}}$ & 4 (bcr2) \& 7 (bcr3) \\
\hline $\operatorname{inv}(16)$ & 1 & $C B F B-M Y H 11$ & $7^{\mathrm{d}}$ & 7 (type F) \\
\hline \multicolumn{5}{|l|}{ (v 11q23) } \\
\hline \multicolumn{5}{|l|}{ ALL } \\
\hline Probe & No. Cases $^{\mathrm{e}}$ & Fusion Gene & No. Cases $^{f}$ & Transcripts \\
\hline $\mathrm{t}(9 ; 22)$ & 9 & $B C R-A B L$ & $18^{\mathrm{g}}$ & 18 (e1a2) \\
\hline (v 11q23) & 10 & $M L L-A F 4$ & $4^{\mathrm{h}}$ & 4 (e8-e7) \\
\hline $\mathrm{t}(1 ; 19)$ & 1 & $E 2 A-P B X 1$ & 1 & 7 (type F) \\
\hline $\mathrm{t}(12 ; 21)$ & 9 & & & \\
\hline $\mathrm{t}(8 ; 14)$ & 2 & & & \\
\hline \multicolumn{5}{|l|}{ CML } \\
\hline Probe & No. Cases ${ }^{\mathrm{i}}$ & Fusion Gene & No. Cases ${ }^{\mathrm{j}}$ & Transcripts \\
\hline $\mathrm{t}(9 ; 22)$ & 7 & $B C R-A B L$ & $65^{\mathrm{k}}$ & $62(\mathrm{~b} 2-\mathrm{a} 2) \& 3(\mathrm{~b} 3 \mathrm{a} 2)$ \\
\hline
\end{tabular}

${ }^{\mathrm{a}}$ FISH analysis in 13 cases; ${ }^{\mathrm{b}} \mathrm{RT}-\mathrm{PCR}$ analysis in 22 cases; ${ }^{\mathrm{c}, \mathrm{d}}$ These results included the positive cases by FISH and other cases without cytogenetic result; ${ }^{\mathrm{e}}$ FISH analysis in 31 cases; ${ }^{\mathrm{f}} \mathrm{RT}$-PCR analysis in 29 cases; ${ }^{\mathrm{g}}$ This result included the positive cases by FISH and other cases without cytogenetic result; ${ }^{\mathrm{h}}$ This result shown the specific fusion gene in $4 / 10$ cases with rearrangement of $11 \mathrm{q} 23$ determined by FISH; ${ }^{\mathrm{i}} \mathrm{FISH}$ analysis in 7 cases; ${ }^{\mathrm{j}} \mathrm{RT}$-PCR analysis in 65 cases; ${ }^{\mathrm{k}}$ This result included the positive cases by FISH and other cases without cytogenetic result.

with ALL, 4 corresponded to the $\mathrm{t}(4 ; 11)$ within the MLL-AF4 fusion gene, in which the transcript e7-e8 was observed in all cases. The $\mathrm{t}(1 ; 19)$ presented the E2APBX1 fusion gene. We identified b2a 2 (95\%) and b3a 2 (5\%) fusion transcripts in CML patients carrying the BCR-ABL fusion gene.

In AML patients with the 11q23 rearrangements and ALL patients with $\mathrm{t}(12 ; 21)$ and $\mathrm{t}(8 ; 14)$ we did not perform RT-PCR analysis.

\section{Discussion}

The incidence of hematological disorders in Ecuador constitutes a major cause of mortality. Geographical heterogeneity was described regarding chromosomal alterations and molecular hematologic problems but the information in Ecuador is limited.

Our group has previously reported on the frequency of BCR-ABL rearrangements in CML and ALL [16,17] and the incidence of follicular lymphoma and $t(14 ; 18)[26]$ in Ecuador. Within this study we present the chromosomal characterization of patients with hematologic disorders who were referred to the genetic analysis, which provides a better understanding of the evolution and prognosis of afflicted individuals. We present data from genetic studies conducted in three reference centers of Quito since 1984, when cytogenetic studies began in Ecuador. These centers analyzed their patients as well as patients referred from ten institutions of various Ecuadorian cities.
Numerical and structural chromosomal abnormalities were detected in $45.9 \%$ of individuals; this is significant in the prognosis of each patient and to their specific response to certain therapeutic agents. In cases where we could not obtain a karyotype, or a normal karyotype was obtained, FISH probes were applied. This allowed us to reveal an average of $1.8 \%$ more alterations, therefore increasing the number of patients classified within each type of blood disease. These alterations were mainly specific translocations associated to leukemia. FISH positive cases were validated by analyzing fusion genes using RT-PCR. All cases positive for AML, ALL and CML presented the following translocations: $t(8 ; 21), \mathrm{t}(15 ; 17)$, $\operatorname{inv}(16), t(9 ; 22)$ and $t(1 ; 19)$. These translocations exhibited the following RT-PCR products respectively: AML1ETO, PML-RARA, CBFB-MYH11, BCR-ABL and E2APBX1. Studies have identified at least 20 partners with translocations involving the MLL gene (11q23) [27]. Within this study only forty per cent of the rearrangements of $11 \mathrm{q} 23$ as evidenced by FISH corresponded to $\mathrm{t}(4 ; 11)$ with the MLL-AF4 fusion gene.

Using RT-PCR allowed us to increase the genetic alterations we observed in the samples analyzed by approximately $4.1 \%$. In the case of CML patients, the $\mathrm{Ph}$ chromosome was detected in $80 \%$ of individuals analyzed by conventional cytogenetics. FISH identified the $t(9 ; 22)$ in cases without metaphases, bringing the cases with CML up to $81 \%$. BCR-ABL detection using RT- 
PCR analysis helped increase the detection of Ph chromosome in $86.9 \%$ of CML cases, representing a significant increase compared to the cytogenetic results.

While this study has focused in the molecular and cytogenetic characterization of hematological neoplasms in an Ecuadorian population, we also examined the frequencies of the different transcript types of fusion genes. Variations in breakpoint sites were correlated to the phenotype and malignancy of leukemia [28]. Cases with $t(8$; 21) (as detected by FISH) showed exclusively the presence of the AML1-ETO fusion gene using RT-PCR. In the case of $t(1 ; 19)$, again identified by FISH, the E2APBX1, showed the most common RT-PCR product.

Rearrangement frequencies of the subtypes b2-a2 $(95 \%)$ and $\mathrm{b} 3 \mathrm{a} 2 \mathrm{2} \%$ ) of BCR-ABL in CML were statistically different to the frequencies reported in other populations [29] and are similar to previously reported data from Ecuadorian patients [16]. In contrast, the e1-a2 rearrangement of the BCR-ABL gene, present in approximately $95 \%$ of ALL patients [25], was detected in $100 \%$ of positive cases in this study. The e8-e7 transcript was visualized in all cases positive for the MLL-AF4 fusion gene. This variant is rare in non-infants and has been reported in less than $10 \%$ of infants. Positive cases had a median age of 7 years (range, 2 - 12 years). The detection of this fusion gene in ALL infants is particularly important because they have a poor response to chemotherapy [30].

The transcripts of the PML-RARA fusion gene corresponded to bcr2 $(36 \%)$ and bcr3 $(64 \%)$. These results are markedly different from the data reported by other groups: bcr1 (55\%), bcr2 (5\%) and bcr3 (40\%) [31]. In our population, none of the AML patients presented the bcrl variant. The presence of a particular variant in a patient or a population can be of particular importance as it could have an effect on treatment response and final outcome [32].

CBFB-MYH11 is associated with a good prognosis [33]. All ALL patients with this fusion gene showed the type $F$ transcript, however in general few cases have been described with this kind of gene transcript. The most frequent transcript is type A, present in more than $85 \%$ of positive cases. Transcripts $\mathrm{D}$ and $\mathrm{E}$, represent about $5 \%$, while others are unique cases [34]. It is noteworthy that although the number of positive cases by RT-PCR was reduced, all were of type F.

The differences in the frequencies of some fusion genes may be a response to the type of the population analyzed. Ecuador has 500 years of history of a mixture between mainly Native Amerindians and Spanish populations. It must also be considered that the differences in the frequency of the different transcripts can be the result of a different genetic component in the Ecuadorian population compared to other populations and that has been observed in studies, reported by our group, involving repair genes associated with NHL and CML $[35,36]$. FISH analysis and RT-PCR methods were used in cases which could not be resolved by conventional cytogenetics in order to obtain results that contribute to patients' diagnosis. The differences in the frequencies of the transcripts of some fusion genes show a different genetic behavior similar to previously described genes related to diseases such as $\triangle \mathrm{F} 508$ in cystic fibrosis, hRAD54 in meningioma and HFE in hemochromatosis [37-39]. Thus, in-depth studies of fusion genes in different hematological malignancies permit a better understanding of the presence of different transcripts and their effect on leukemia.

\section{Acknowledgements}

We would like to thank Melissa Arévalo (HCAM), Catherine Carrera (SOLCA), Mirian Espín (SOLCA), Alicia Godoy (HCAM) and Janeth Nájera (HCAM) for technical assistance.

\section{REFERENCES}

[1] Facts 2013, "Leukemia \& Lymphoma Society," 2013. http://www.lls.org/content/nationalcontent/resourcecenter /freeeducationmaterials/generalcancer/pdf/facts.pdf

[2] P. Cueva and J. Yérez, "National Cancer Registry: Cancer Epidemiology in Quito 2003-2005," Sociedad de Lucha contra el Cáncer, Quito, 2009.

[3] M. San Sebastián and A. K. Hurtig, "Cancer among Indigenous People in the Amazon Basin of Ecuador, 19852000," Revista Panamericana de Salud Pública, Vol. 16, No. 5, 2004, pp. 328-333.

[4] J. Ferlay, H. R. Shin, F. Bray, D. Forman, C. Mathers, and D. M. Parkin, "GLOBOCAN 2008 v2.0, Cancer Incidence and Mortality Worldwide," Lyon, France, IARC Cancer-Base No. 10 [Internet]: International Agency for Research on Cancer, 2010. http://globocan.iarc.fr

[5] C. Y. Meng, P. J. Noor, A. Ismail, M. F. Ahid and Z. Zakaria, "Cytogenetic Profile of De Novo Acute Myeloid Leukemia Patients in Malaysia," International Journal of Biomedical Science, Vol. 9, No. 1, 2013, pp. 26-32.

[6] D. Rowe, S. J. Cotterill, F. M. Ross, D. J. Bunyan, S. J. Vickers, J. Bryon, et al., "Cytogeneticaly Cryptic AML1ETO and CBF Beta-MYH11 Gene Rearrangements: Incidence in 412 Cases of Acute Myeloid Leukemia," British Journal of Haematology, Vol. 111, No. 4, 2000, pp. 1051-1056. http://dx.doi.org/10.1111/j.1365-2141.2000.02474.x

[7] C. Schoch, S. Schnittger, W. Kern, E. Lengfelder, H. Löffler, W. Hiddemann, et al., "Rapid Diagnostic Approach to PML-RARA-Positive Acute Promyelocytic Leukemia," The Hematology Journal, Vol. 3, No. 5, 2002, pp. 259-263. http://dx.doi.org/10.1038/sj.thj.6200181

[8] F. Marchesi, O. Annibali, E. Cerchiara, M. C. Tirindelli and G. Avvisati, "Cytogenetic Abnormalities in Adult 
Non-Promyelocytic Acute Myeloid Leukemia: A Concise Review," Critical Reviews in Oncology/Hematology, Vol. 80, No. 3, 2011, pp. 331-346. http://dx.doi.org/10.1016/i.critrevonc.2010.11.006

[9] M. Mangolini, J. de Boer, V. Walf-Vorderwülbecke, R. Pieters, M. L. den Boer and O. Williams, "STAT3 Mediates Oncogenic Addiction to TEL-AML1 in $\mathrm{t}(12 ; 21)$ Acute Lymphoblastic Leukemia," Blood, Vol. 122, No. 4, 2013 , pp. 542-549.

http://dx.doi.org/10.1182/blood-2012-11-465252

[10] A. Daniel-Cravioto, C. R. Gonzalez-Bonilla, J. M. MejiaAranque, M. L. Perez-Saldivar, A. Fajardo-Gutierrez, E. Jimenez-Hernandez, et al., "Genetic Rearrangement MLL/ AF4 Is Most Frequent in Children with Acute Lymphoblastic Leukemias in Mexico City," Leukemia \& Lymphoma, Vol. 50, No. 8, 2009, pp. 1352-1360. http://dx.doi.org/10.1080/10428190903015636

[11] M. Aricò, M. G. Valsecchi, B. Carmita, M. Schappe, J. Chessells, A. Baruchel, et al., "Outcome of Treatment in Children with Philadelphia Chromosome-Positive Acute Lymphoblastic Leukemia," The New England Journal of Medicine, Vol. 342, No. 14, 2000, pp. 998-1006. http://dx.doi.org/10.1056/NEJM200004063421402

[12] M. C. Castro-Mujica and Y. Sullcahuamán-Allende, "Molecular Subtypes of PML/RAR $\alpha$ in Patients with Acute Promyelocytic Leukemia," Revista Peruana de Medicina Experimental y Salud Pública, Vol. 30, No. 1, 2013, pp. 37-40. http://dx.doi.org/10.1590/S1726-46342013000100007

[13] D. Douer, S. Santillana, L. Ramezani, C. Samanez, M. L. Slovak, M. S. Lee, et al., "Acute Promyelocytic Leukaemia in Patients Originating in Latin America Is Associated with an Increased Frequency of the bcrl Subtype of the PML/RARalpha Fusion Gene," British Journal of Haematology, Vol. 122, No. 4, 2003, pp. 563-570. http://dx.doi.org/10.1046/j.1365-2141.2003.04480.x

[14] K. Inokuchi, T. Inoue, A. Tojo, M. Futaki, K. Miyake, T. Yamada, et al., "A Possible Correlation between the Type of bcr-abl Hybrid Messenger RNA and Platelet Count in Philadelphia-Positive Chronic Myelogenous Leukemia," Blood, Vol. 78, No.12, 1991, pp. 3125-3127.

[15] C. Udomsakdi-Auewarakul, Y. U-Pratya, S. Boonmoh and S. Vatanavicharn, "Detection of Molecular Variants of BCRABL Gene in Bone Marrow and Blood of Patients with Chronic Myeloid Leukemia by Reverse-Transcriptase Polymerase Chain Reaction (RT-PCR)," Journal of the Medical Association of Thailand, Vol. 83, No. 8, 2000, pp. 928-935.

[16] C. Paz-y-Miño, R. Burgos, S. A. Morillo, J. C. Santos, B. F. Fiallo and P. E. Leone, "BCR-ABL Rearrangement Frequencies in CML and ALL in Ecuador, South America," Cancer Genetics and Cytogenetics, Vol. 132, No. 1, 2002, pp. 65-67.

[17] C. Paz-y-Miño, M. Arévalo and P. E. Leone, "B3/A3 Rearrangement in a Patient with Chronic Myeloid Leukemia," Leukemia and Lymphoma, Vol. 44, No. 2, 2003, pp. 375-376. http://dx.doi.org/10.1080/1042819021000029678

[18] American Cancer Society, "Global Cancer Facts \& Figures," 2nd Edition, American Cancer Society, Atlanta,
2011.

[19] D. Sugapriya, S. Preethi, P. Shanhi, N. Chandra, G. Jeyaraman, P. Sachdanandam, et al., "BCR-ABL Translocation in Pediatric Acute Lymphoblastic Leukemia in Southern India," Indian Journal of Hematology \& Blood Transfusion, Vol. 28, No. 1, 2012, pp. 37-41. http://dx.doi.org/10.1007/s12288-011-0096-9

[20] M. Zucca, J. Ugalde, F. S. Arteaga, G. Biggio, V. Flore, T. Nonne, et al., "Leukemia in Children and Youths of the Azuay Province, Ecuador: 2000-2010," International Journal of Environmental Health Research, Vol. 23, No. 1, 2013, pp. 58-65. http://dx.doi.org/10.1080/09603123.2012.699028

[21] L. G. Shaffer, J. McGowan-Jordan and M. Schmid, "ISCN 2013: An International System for Human Cytogenetic Nomenclature (2013)," Karger, Basel, 2013.

[22] J. M. Mejía-Aranguré, M. Bonilla, R. Lorenzana, S. JuárezOcaña, G. de Reyes, M. L. Pérez-Saldivar, et al., "Incidence of Leukemias in Children from El Salvador and Mexico City between 1996 and 2000: Population-Based Data," BMC Cancer, Vol. 5, 2005, p. 33. http://dx.doi.org/10.1186/1471-2407-5-33

[23] Ministerio De Salud, "Guía Clínica Leucemia Del Adulto," Minsal, Santiago, 2007.

[24] P. Chomczynski and N. Sacchi, "Single-Step Method of RNA Isolation by Acid Guanidinium Thiocyanate-Phenol-Chloroform Extraction," Analytical Biochemistry, Vol. 162, No. 1, 1987, pp. 156-159.

http://dx.doi.org/10.1016/0003-2697(87)90021-2

[25] J. J. M. van Dongen, E. A. Macintyre, J. A. Gabert, E. Delabesse, V. Rossi, G. Saglio, et al., "Standardized RTPCR Analysis of Fusion Gene Transcripts from Chromosome Aberrations in Acute Leukemia for Detection of Minimal Residual Disease," Leukemia, Vol. 13, No. 12, 1999, pp. 1901-1928. http://dx.doi.org/10.1038/sj.leu.2401592

[26] P. E. Leone, J. C. Pérez, S. A. Morillo and C. Paz-y-Miño, "Low Incidence of Follicular Lymphoma and $t(14 ; 18)$ (q32;q21) by Polymerase Chain Reaction Analysis: Observations on Ecuadorian Patients," Cancer Genetics and Cytogenetics, Vol. 137, No. 1, 2002, pp. 72-74. http://dx.doi.org/10.1016/S0165-4608(02)00542-3

[27] C. J. Harrison, A. Cuneo, R. Clark, B. Johansson, M. Lafage-Pochitaloff, F. Mugneret, et al., "Ten Novel 11q23 Chromosomal Partner Sites. European 11q23 Workshop participants," Leukemia, Vol. 12, No. 5, 1998, pp. 811822. http://dx.doi.org/10.1038/sj.leu.2401017

[28] J. V. Melo, "The Diversity of BCR-ABL Fusion Proteins and Their Relationship to Leukemia Phenotype," Blood, Vol. 88, No. 7, 1996, pp. 2375-2384.

[29] J. P. Meza-Espinoza, M. Gutiérrez-Angulo, A. VázquezCárdenas, J. L. Delgado-Lamas, M. A. Esparza-Flores and J. R. González-García, "Prevalence of the BCR/ABL1 Transcripts in Mexican Patients with Chronic Myelogenous Leukemia," Revista de Investigación Clínica, Vol. 59, No. 5, 2007, pp. 338-341.

[30] C. H. Pui and W. E. Evans, "Acute Lymphoblastic Leukemia," The New England Journal of Medicine, Vol. 339, 
No. 9, 1998, pp. 605-615. http://dx.doi.org/10.1056/NEJM199808273390907

[31] A. Biondi, A. Rambaldi, P. P. Pandolfi, V. Rossi, G. Giudici, M. Alcalay, et al., "Molecular Monitoring of the myl/Retinoic Acid Receptor-Alpha Fusion Gene in Acute Promyelocytic Leukemia by Polymerase Chain Reaction," Blood, Vol. 80, No. 2, 1992, pp. 492-497.

[32] F. Lo Coco, D. Diverio, B. Falini, A. Biondi, C. Nervi and P. G. Pelicci, "Genetic Diagnosis and Molecular Monitoring in the Management of Acute Promyelocytic Leukemia," Blood, Vol. 94, No. 1, 1999, pp. 12-22.

[33] D. Grimwade, H. Walker, F. Oliver, K. Wheatley, C. Harrison, G. Harrison, et al., "The Importance of Diagnostic Cytogenetics on Outcome in AML: Analysis of $1612 \mathrm{~Pa}-$ tients Entered into the MRC AML 10 Trial. The Medical Research Council Adult and Children's Leukaemia Working Parties," Blood, Vol. 92, No. 7, 1998, pp. 23222333.

[34] P. P. Liu, A. Hajra, C. Wijmenga and F. S. Collins, "Molecular Pathogenesis of the Chromosome 16 Inversion in the M4Eo Subtype of Acute Myeloid Leukemia," Blood, Vol. 85, No. 9, 1995, pp. 2289-2302.

[35] C. Paz-y-Miño, J. C. Pérez, B. F. Fiallo and P. E. Leone, "A Polymorphism in the hMSH2 Gene [gIVS12-6T $>\mathrm{C}$ ] Associated with Non-Hodkin Lymphomas," Cancer Ge- netics and Cytogenetics, Vol. 133, No. 1, 2002, pp. 29-33. http://dx.doi.org/10.1016/S0165-4608(01)00547-7

[36] C. Paz-y-Miño, A. López-Cortés, M. J. Muñoz, B. Castro, A. Cabrera and M. E. Sánchez, "Relationship of an hRAD54 Gene Polymorphism (2290 C/T) in an Ecuadorian Population with Chronic Myelogenous Leukemia," Genetics and Molecular Biology, Vol. 33, No. 4, 2010, pp. 646-649. http://dx.doi.org/10.1590/S1415-47572010005000095

[37] C. Paz-y-Miño, J. C. Pérez, R. Burgos, M. V. Dávalos and P. E. Leone, "The $\Delta$ F508 Mutation in Ecuador, South America," Human Mutation, Vol. 14, No. 4, 1999, pp. 348-350.

http://dx.doi.org/10.1002/(SICI)1098-1004(199910)14:4< 348::AID-HUMU11>3.0.CO;2-8

[38] P. E. Leone, M. Mendiola, J. Alonso, C. Paz-y-Miño and A. Pestaña, "Implications of a RAD54L Polymorphism $(2290 \mathrm{C} / \mathrm{T})$ in Human Meningiomas as a Risk Factor and or a Genetic Marker," BMC Cancer, Vol. 3, 2003, p. 6. http://dx.doi.org/10.1186/1471-2407-3-6

[39] P. E. Leone, P. Giménez, J. C. Collantes and C. Paz-yMiño, "Analysis of HFE Gene Mutations (C282Y, H63D, and $\mathrm{S} 65 \mathrm{C}$ ) in the Ecuadorian Population," Annals of Hematology, Vol. 84, No. 2, 2005, pp. 103-105. http://dx.doi.org/10.1007/s00277-004-0966-4 